\title{
Identifying ecotourists' accommodation needs and preferences?
}

\author{
M. Saayman ${ }^{a \star}$ and P. van der Merwe ${ }^{b}$ \\ ${ }^{a}$ Tourism Research in Economic Environs and Society, North-West University, Potchefstroom Campus, South Africa \\ ${ }^{\mathrm{b} S} \mathrm{School}$ of Business Management: Tourism Program, North-West University, Potchefstroom Campus, South Africa
}

*To whom all correspondence should be addressed

Melville.Saayman@nwu.ac.za

\begin{abstract}
The purpose of this research is to determine ecotourists' needs and preferences concerning national parks in South Africa. A survey was conducted at the Tsitsikamma National Park, focusing on fixed-roof accommodation, camping and ecolodges. Results showed that the preferences for each aspect are unique and that setting remains paramount when it comes to fixedroof accommodation. The research also confirmed that a variety of accommodation types, including provision for selfcatering, is preferred by ecotourists. This research makes a valuable contribution to the managing of accommodation in South African National Parks.
\end{abstract}

\section{Introduction}

Nature-based travel is one of the key reasons why tourists travel to South Africa; this is most probably true for most countries in Africa (Saayman, Rossouw \& Saayman, 2012). With increased travel to nature-based attractions, an increased popularity of ecolodges as accomodation has emerged (Kwan, Eagles \& Gebhardt, 2010). These increases in demand for accommodation have led to a steep growth in the supply or development of different types of accommodation, from the original tents and rondawels (circular and often thatched buildings with conical roofs) in the early 1900s to the luxurious tents and chalets of today. In this context, Wight (1997) found that ecotourists are looking for a range of products and that setting is of paramount importance; this includes uncrowded wilderness and remoteness. The experience, according to Wight (1997), determines their accommodation preferences and not vice versa. From a South African nature-based travelling perspective, the two main forms of accommodation are still camping (tents and caravans) and fixed-roof accommodation (chalets, forest huts, wilderness camps and guest houses) to name but a few (Saayman, 2007). Therefore, this research will focus on these types of accommodation.

Because accommodation plays such an important role in the tourist's experience, one would imagine that many studies concerning this topic have been conducted. However, Kwan et al. (2010) noted that, despite the growth in both demand and supply, very few studies have been conducted on this topic. The gap or lack of research led to this study that wants to address the question what do ecotourists regard as important when they select accommodation in nature-based areas? In other words, what are their accommodation needs and preferences and what is the management implication? The answer to this is extremely important, since it covers a wide variety of aspects such as the size of ecolodges (how many people it can accommodate), level of luxury, type of accommodation, layout and required facilities (showers/baths/toilets etc.), how environmentally friendly these lodges should be, whether it should be rated or graded and whether it should be fenced to keep dangerous animals out. These aspects play an important role in decision making. The purpose of this paper, therefore, is to identify the accommodation needs and preferences of ecotourists; the paper differs from other similar studies in that it addresses fixed-roof accommodation, camping and ecolodge preferences. This type of research becomes very important, as ecotourism is not only a growing market, but ecotourists also influence general travellers' preferences (Wight, 1997).

\section{Literature review}

The literature review consists of two sections: a brief overview of nature-based accommodation in South Africa, and accommodation needs and preferences.

\section{A brief overview of nature-based accommodation in South Africa}

Traditionally, tourists or adventurers who travel in and to South Africa and Southern Africa have used tents for accomodation, despite the dangers of being attacked by wild animals (Carruthers, 1995). The first and oldest national park in South Africa and also one of the oldest in the world that offered nature-based accommodation was the Kruger National Park and the most popular form or type of fixed-roof accommodation that was available in this park was called a rondawel. This was a typical and popular form of accommodation of the time and was also used by several tribes in South Africa such as the Zulus and Xhosas. Since then, the type of accommodation in nature-based attractions has expanded rapidly and currently includes chalets, fixed tents, tree houses, wilderness camps, guesthouses and forest huts. In the early 1900s to the 1970s, accommodation establishments (especially in national parks) consisted of a 
large number of accommodation units, usually referred to as "rest camps", built in the shape of a circle or square, with these units facing towards the centre of the circle or square. Since the 1980s, the number of accommodation units per camp or lodge decreased. Currently, most of the new developments are far less in number of units (six to eight) and are referred to as "ecolodges" and not rest camps. In this context, Mehta, Baez and O'Loughlin (2002) state that for an accommodation establishment to be labelled an ecolodge, it must fulfil three basic criteria that also embody the key principles of ecotourism, namely that it must (1) conserve the land where it is located; (2) benefit local communities; and (3) offer an enlightening experience. In the context of this research, lodges in national parks comply with these criteria. Morrison (2002) states that an ecolodge is categorised as a type of small, specialist accommodation that is similar to a small hotel or guesthouse. Russel et al. (1995) also support the notion that an ecolodge should enhance and embrace the philosophy and principles of ecotourism.

The focus has also changed to giving the tourist a more authentic experience in which less people can "intrude", implying that in the latest type of accommodation, places do not face one another, but rather faces away for a wilderness experience that gives the ecotourist greater privacy. With the growth of ecotourism and wildlife management practices in South Africa, the number of privately owned game farms or game reserves has increased to approximately 9000 (Van Hoven, 2005). The number of national parks is 21 and in addition, there are more than 130 provincial parks; this makes the ecotourism environment very competitive (Van der Merwe \& Saayman, 2008). In South Africa, like in most Southern African countries, nature-based products are located in areas where one can encounter dangerous animals such as the Big 5 (elephant, rhino, lion, buffalo and leopard), which implies that lodges need to take these aspects into account as well. This requires knowledge of what the tourists prefer or expect. In short, what are their accommodation needs and preferences?

\section{Accommodation needs and preferences}

Accommodation is a key or primary component of tourism, since tourists require a place to stay. It is also one of the biggest job suppliers in the tourism industry and therefore very important. In general, ecotourists spend $49 \%$ of their total expenditure on accommodation per trip (Saayman \& Scholtz, 2012). Even though many studies are conducted in the broader accommodation sector, few are conducted in the ecotourism sector and even less focus on the needs and preferences of ecotourists. Those that are available, address ecotourists' motivations (Chan \& Baum, 2007; Garst, Williams \& Roggenbuch, 2010; Brooker \& Joppe, 2013; Clark, Hendee \& Chambel, 2009), profiles (Kwan et al., 2010; IFC, 2002; Cini \& Saayman, 2013) and economics (Sanders \& Halpenny, 2001; Saayman et al., 2012; Kruger et al., 2014). According to Figure 1, the variety of accommodation (and therefore experiences) also influences where tourists fall within the spectrum, ranging from hard to soft ecotourists; it therefore makes provision for a variety of needs and preferences. This fact still begs an answer to the question: What are the attributes or aspects that ecotourists are looking for in order to fulfil their needs and preferences?

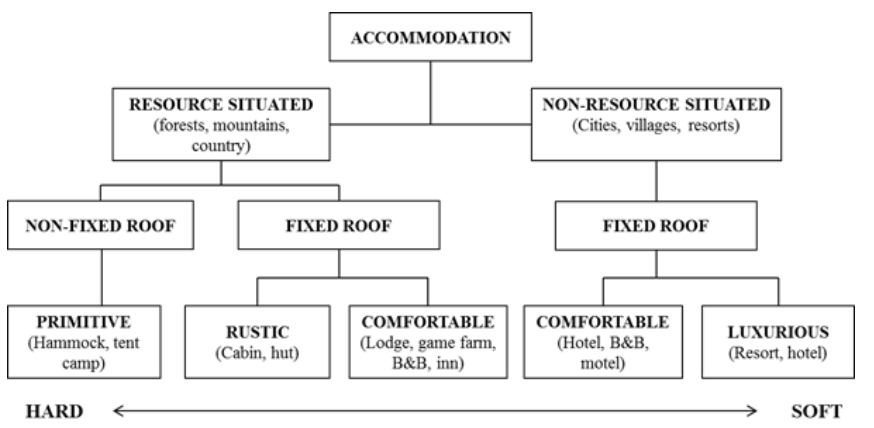

Figure 1. Ecotourism accommodation spectrum Adapted from Wight (1997)

The International Finance Corporation (IFC, 2004) compiled a report on ecolodge development and ecotourists' preferences, showing that ecotourists are looking for value for money and more traditional accommodation that is ecofriendly. In addition, that accommodation should be located near places where movement of wildlife can be observed; it should have high scenic qualities; and the architectural design should adhere to sensitive practices. Dolnicor, Crouch and Lang (2008) concur with this in their study regarding ecotourists, "What do we know about them?", in which they indicated that the most important aspect that ecotourists look for in nature-based products is the natural location. In a study that was conducted by Kwan et al. (2010), the researchers found that when selecting an ecolodge, the highest rated attributes were friendly staff, scenery, value for money, decent sanitary conditions, and quality of the environment and landscape. Engelbrecht, Saayman and Kruger (2014) also confirmed the importance of hygiene as a key success factor in managing national parks. The lowest rated attributes included business and conference facilities, horse trails, the availability of research facilities, onsite entertainment, sales and rental services for recreational equipment. Tsagarakis et al. (2011) found in their study that more than $85 \%$ of tourists prefer accommodation that relies on energy-saving systems or renewable energy; in other words, they prefer accommodation that is greener or more ecofriendly. This confirms research by Du Plessis, Van der Merwe and Saayman (2013) concerning ecofriendly management practices in national parks. Ceballos-Luscariun and Metha (2002) add to this and state that an ecolodge should be designed within the natural physical context of the area in which it is situated.

In an ecolodge consumer survey with a focus on segmenting ecotourists, research by Weaver and Lawton (2002) identified three distinct segments, namely hard, soft and structural. The harder ecotourists preferred backpacker accommodation, camping and recreational vehicles. The softer ecotourists enjoyed beach resorts and the structural ecotourists preferred high-level services and facilities. Research by Kwan et al. (2010), Du Plessis et al. (2013), Wight (1997), Tsagarakis et al. (2011), IFC (2002), Kruger, Scholtz and Saayman (2012) 
and Chan and Baum (2007) revealed the following trends or preferences concerning ecotourists:

- Ecotourism is growing, which necessitates a greater variety of accommodation.

- More tourists travel to remote areas.

- Different markets with different needs, ranging from soft to hard ecotourists, exist.

- Competition amongst destinations is growing and this is also true when one looks at different accommodation facilities.

- Ecotourists travel for different reasons.

- More tourists are becoming more environmentally friendly.

- There has been a shift in the type of required accommodation.

- Privacy is becoming more important.

- Ecotourists are looking for more authentic experiences.

These trends and preferences have an impact on what tourists regard as important; they are therefore paramount for ecolodge planning and development, and thus for this research.

\section{Method of research}

This exploratory research was quantitative in nature and was approached under the following headings: the study area, the questionnaire, sampling and survey, and statistical analysis.

\section{Study area}

Because of the variety of accommodation on offer, the Tsitsikamma National Park, the oldest marine park in Africa, was chosen for the research. The park offers forest huts, guest houses, a campsite (rated as one of the best camp sites in South African National Parks), chalets and log cabins (SANParks, 2015).

\section{Questionnaire}

The questionnaire consists of three sections: Section A determined the socio-demographic profile (including aspects such as age gender, language and place of residence) (see Kruger et al., 2012; Van der Merwe \& Saayman, 2008); Section B determined accommodation preferences (including aspects such as accommodation types, where units are located and bathroom preferences); and Section C determined the travel motives of respondents (including aspects such as relaxation, escape and novelty) (Saayman, Van der Merwe \& Pienaar, 2009). Section B (that is relevant to this research) was based on the work of Metha, Baèz and O'Loughlin (2002), the International Financial Corporation (2004), Lewis (TIES) and the International Ecotourism Society (TIES) (2015). Three aspects formed part of Section B and focused on (a) fixed-roof accommodation in national parks; (b) campsites; and (c) ecolodge preferences. Fixed-roof accommodation preferences had 43 constructs, campsite preferences had 16 constructs and ecolodge preferences had
30 constructs. A five-point Likert scale was used in which one was not at all important and five was extremely important.

\section{Sampling and survey}

Based on purposive sampling, all tourists to the Tsitsikamma National Park, during the period of the survey that took place from 17 to 24 April 2014, formed part of the survey. Early in the evenings, the questionnaires were distributed by trained fieldworkers and then collected an hour later. One questionnaire per family or travel group was distributed per accommodation unit or campsite. A total of 230 questionnaires were distributed, of which 202 were fully completed during the survey and these were used in the statistical analysis.

\section{Statistical analysis}

Microsoft Excel ${ }^{\mathrm{TM}}$ was used to capture the data that were collected from questionnaires, and IBM® SPSS $®$ Statistics V22.0 (Statistical Package of Social Sciences) software was used to process captured data and descriptive and factor analyses.

A factor analysis is a statistical method that is used to identify whether or not a linear relationship exists between a large number of variables, in this case the adventure activities/items, and a smaller number of unobservable factors (Child, 2006:1). The pattern matrix technique was used for conducting the factor analyses on both the soft and hard adventure activities, and Cronbach's alpha was used to determine the internal consistency of factors, otherwise known as consistency in measurement (Wigley, 2011:282).

Factors were determined by using Kaisers's criterion and were selected if it had an eigenvalue of 1 or more (Pallant, 2010:181). Using a pattern matrix, eight factors were identified for soft adventure activities and three factors for hard adventure activities. High correlation values were documented between all factors, whereby all items loaded on A-factors had a loading greater than 0.3. Items with double loadings were grouped according to the factors that they represented best and also according to the highest loading values. Total variance explained for analyses that were above $50 \%$, indicating an appropriate fit of the selected components (Pietersen \& Maree, 2007:218).

\section{Results}

The results are divided into four parts, namely the profile of respondents, and the needs and preferences of fixed-roof accommodation in national parks, campsites and ecolodges.

\section{Profile of respondents}

It is clear that national parks are well known by the respondents, as the latter had visited national parks more than six times in the last five years; $49 \%$ were male and $51 \%$ female, $48 \%$ were Afrikaans speaking, their average age was $35-49$ years and $73 \%$ were married. These tourists prefer self- 
catering and most of the international visitors were from Germany (50\%) and the Netherlands (15\%), whereas most local tourists came from the Western Cape (39\%) and Eastern Cape provinces $(31 \%)$. The profile of these results correlates well with previous research that has been conducted by Hermann (2015), Engelbrecht (2015), Cini \& Saayman (2013), Kruger et al. (2012), Saayman et al. (2008) and Van der Merwe and Saayman (2008), who determined the profile of tourists visiting South African National Parks.

\section{Aspects of importance when selecting fixed-roof accommodation in national parks}

From the 43 constructs that were measured regarding aspects of importance in selecting fixed-roof accommodation in national parks, 11 factors were extracted, namely wilderness accommodation type, guest house, ambiance, cooking area, setting, amenities, ablution, green facilities, size of camps, chalets and pricing (Table 1). Two of these factors were discarded, namely Factor 9 (size of camp) that had only one construct and therefore no Cronbach's alpha value and Factor 11 (pricing) whose Cronbach's alpha was lower than the recommended value of 0.600 (Field, 2006). The remaining
Cronbach's alphas were between 0.646 and 0.892 which, according to Field (2006), is satisfactory. The factor with the highest mean value (4.00) was Factor 5 (cooking area), followed by Factor 4 (setting) with a mean value of 3.96, Factor 7 (ablution) with a mean value of 3.85, Factor 8 (green factor) with a mean value of 3.70 , Factor 10 (chalets) with a mean value of 3.33 and Factor 3 (ambience) with a mean value of 3.24. The remaining three factors had mean values that were less than three on the five-point Likert scales and are therefore seen as not at all important to important.

From the factor analysis (Table 1), the three most important aspects that are taken into consideration by respondents when selecting fixed-roof accommodation in national parks are cooking area, setting and ablution. "Cooking area" refers to the availability of braai (barbeque) facilities and an outside cooking area. Setting refers to the location (near wildlife), the absence of unpleasant sounds such as vehicle and human noises, the opportunity to experience wildlife and to be one with nature/wildlife, and units that embrace ecological alternatives. Ablution includes aspects such as the necessity of either a shower or a bath, and the necessity of an inside shower.

\section{Table 1: Aspects of importance when selecting fixed-roof accommodation in national parks}

\section{CONSTRUCTION}

Variance explained $67.18 \%$

\section{Cronbach's alpha}

Mean value

Inter-item correlations

Tree tents

Tented camps

Safari tents

Treetop chalets

Mountain cabins

Log cabins

Self-catering guesthouse (that can

accommodate more than one family)

Guesthouse (full board: dinner/bed/breakfast)

Dormitory (backpackers)

Luxury accommodation units (5-star,

SANParks concessions)

Budget accommodation units (shared

communal facilities)

Cosy atmosphere (e.g. fireplace and lounge

area)

Units must have a porch ("stoep").

Locally made bedding and table cloths should

be used.

Units must be located near highly viewable

wildlife resources (waterholes, mountains,

rivers and forests).

Units must not be exposed to human noise,

traffic or artificial lighting.

Units must provide tourists with the

opportunity to experience wildlife and nature

(i.e., close to nature and no fences).

Units should embrace ecological alternatives

(e.g. thatched roofs, solar energy and natural

heating/cooling).

FACTORS

\begin{tabular}{|c|c|c|c|c|c|c|c|c|c|c|}
\hline \multicolumn{11}{|c|}{ FACTORS } \\
\hline 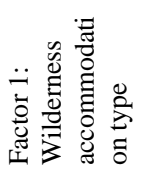 & 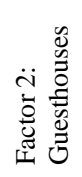 & 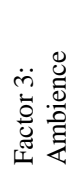 & 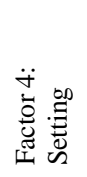 & 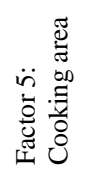 & 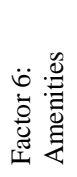 & 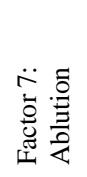 & 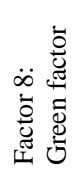 & 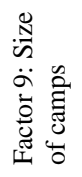 & 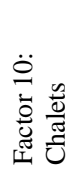 & 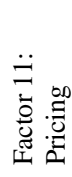 \\
\hline 0.892 & 0.714 & 0.646 & 0.832 & 0.692 & 0.680 & 0.638 & 0.574 & & 0.679 & 0.313 \\
\hline 2.95 & 2.47 & 3.24 & 3.96 & 4.00 & 2.51 & 3.85 & 3.70 & 2.83 & 3.33 & \\
\hline 0.581 & 0.335 & 0.386 & 0.460 & 0.531 & 0.305 & 0.386 & 0.310 & & 0.418 & 0.186 \\
\hline 0.841 & & & & & & & & & & \\
\hline 0.820 & & & & & & & & & & \\
\hline 0.795 & & & & & & & & & & \\
\hline 0.790 & & & & & & & & & & \\
\hline 0.713 & & & & & & & & & & \\
\hline 0.568 & & & & & & & & & & \\
\hline & 0.746 & & & & & & & & & \\
\hline & 0.679 & & & & & & & & & \\
\hline & 0.650 & & & & & & & & & \\
\hline & 0.387 & & & & & & & & & \\
\hline & 0.442 & & & & & & & & & \\
\hline & & 0.761 & & & & & & & & \\
\hline & & 0.630 & & & & & & & & \\
\hline & & 0.506 & & & & & & & & \\
\hline & & & 0.719 & & & & & & & \\
\hline & & & 0.715 & & & & & & & \\
\hline & & & 0.660 & & & & & & & \\
\hline & & & 0.534 & & & & & & & \\
\hline
\end{tabular}


CONSTRUCTION

\begin{tabular}{|c|c|c|c|c|c|c|c|c|c|c|c|}
\hline CONSTRUCTION & & & & & FA & TORS & & & & & \\
\hline Variance explained $67.18 \%$ & 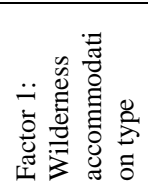 & 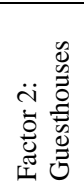 & 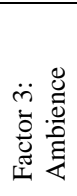 & 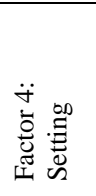 & 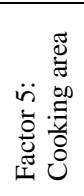 & 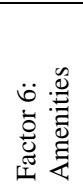 & 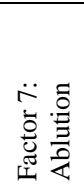 & 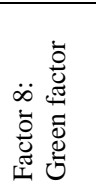 & 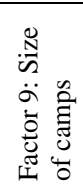 & 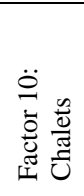 & 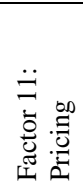 \\
\hline Units must have a scenic view. & & & & 0.518 & & & & & & & \\
\hline $\begin{array}{l}\text { Units must allow tourists to feel one with } \\
\text { nature. }\end{array}$ & & & & 0.505 & & & & & & & \\
\hline Units must have a braai facility. & & & & & 0.851 & & & & & & \\
\hline Units must have outside cooking areas. & & & & & 0.609 & & & & & & \\
\hline Units must have outside shower facilities. & & & & & & 0.701 & & & & & \\
\hline $\begin{array}{l}\text { Different units must each have separate } \\
\text { themes/décor. }\end{array}$ & & & & & & 0.661 & & & & & \\
\hline Units must be in an area with the Big Five. & & & & & & 0.584 & & & & & \\
\hline Units must have both a bath and a shower. & & & & & & $\begin{array}{r}- \\
0.518\end{array}$ & & & & & \\
\hline $\begin{array}{l}\text { Units must fit in with local culture and } \\
\text { traditions. }\end{array}$ & & & & & & 0.373 & & & & & \\
\hline Units must have either a bath or a shower. & & & & & & & 0.843 & & & & \\
\hline Units must have inside shower facilities. & & & & & & & 0.352 & & & & \\
\hline Units must have an inside cooking area. & & & & & & & 0.418 & & & & \\
\hline $\begin{array}{l}\text { Units must have a natural heating and cooling } \\
\text { design. }\end{array}$ & & & & & & & & 0.706 & & & \\
\hline Units must be open planned. & & & & & & & & 0.556 & & & \\
\hline $\begin{array}{l}\text { Units must be comfortable and functional (easy } \\
\text { to move in-/outside). }\end{array}$ & & & & & & & & 0.530 & & & \\
\hline Units must fit the natural surroundings. & & & & & & & & 0.523 & & & \\
\hline $\begin{array}{l}\text { There should be less accommodation units per } \\
\text { rest camp. }\end{array}$ & & & & & & & & & 0.521 & & \\
\hline Chalets & & & & & & & & & & 0.764 & \\
\hline $\begin{array}{l}\text { Economy accommodation units (en suite } \\
\text { bathroom and kitchen area) }\end{array}$ & & & & & & & & & & 0.639 & \\
\hline Bungalows & & & & & & & & & & 0.620 & \\
\hline $\begin{array}{l}\text { The price must be comparable with other } \\
\text { similar products. }\end{array}$ & & & & & & & & & & & 0.637 \\
\hline The units must be very basic, but clean. & & & & & & & & & & & 0.343 \\
\hline
\end{tabular}

\section{Campsite preferences}

Campsite preferences refer to accommodation areas where tourists make use of their own tents or caravans. National parks provide ablution facilities and, where possible, electrical power points. 16 constructs formed part of the factor analysis, of which five factors were extracted, namely exclusivity, wilderness attributes, shared ablution facilities, amenities and shower/baths. Factor 5 revealed low Cronbach's alphas and will, therefore, not be used in the results. The factor with the highest mean value was exclusivity (with a mean value of 3.68), followed by amenities (with a mean value of 3.16), wilderness attributes and shared ablution facilities (each with a mean value of 3.05, respectively). Factor 1 (exclusivity) is rated as the most important factor and includes constructs such as water and an electricity point, small private ablutions and a private braai facility for each campsite. Factor 4 (amenities) includes constructs such as the availibility of wilderness trailer rent from national parks, rooftop tents and the availibility of a laundromat on campsites. 
Table 2: Campsite preferences

\begin{tabular}{|c|c|c|c|c|c|}
\hline Variance explained $66.74 \%$ & $\begin{array}{l}\text { Factor 1: } \\
\text { Exclusivity }\end{array}$ & $\begin{array}{l}\text { Factor 2: } \\
\text { Wilderness } \\
\text { attributes }\end{array}$ & $\begin{array}{c}\text { Factor 3: } \\
\text { Shared ablution } \\
\text { facilities }\end{array}$ & $\begin{array}{l}\text { Factor 4: } \\
\text { Amenities }\end{array}$ & $\begin{array}{l}\text { Factor 5: } \\
\text { Showers/Baths }\end{array}$ \\
\hline Cronbach's alpha & 0.782 & 0.729 & 0.556 & 0.714 & 0.423 \\
\hline Mean value & 3.68 & 3.05 & 3.05 & 3.16 & \\
\hline Inter-item correlations & 0.422 & 0.407 & 0.385 & 0.455 & 0.270 \\
\hline $\begin{array}{l}\text { Each campsite stand must have its } \\
\text { own water point (tap). }\end{array}$ & 0.813 & & & & \\
\hline $\begin{array}{l}\text { Each campsite stand must have its } \\
\text { own electricity outlet. }\end{array}$ & 0.741 & & & & \\
\hline $\begin{array}{l}\text { Each stand should have its own } \\
\text { small private ablution and wash-up } \\
\text { area. }\end{array}$ & 0.670 & & & & \\
\hline $\begin{array}{l}\text { Each campsite stand must have its } \\
\text { own braai facility. }\end{array}$ & 0.666 & & & & \\
\hline $\begin{array}{l}\text { All campsite stands must be } \\
\text { closely located to ablution } \\
\text { facilities and wash-up areas. }\end{array}$ & 0.552 & & & & \\
\hline $\begin{array}{l}\text { Wilderness campsites with no } \\
\text { facilities (no toilets \& showers) }\end{array}$ & & 0.748 & & & \\
\hline $\begin{array}{l}\begin{array}{l}\text { Wilderness camps (4-8 private } \\
\text { units) }\end{array} \\
\end{array}$ & & 0.745 & & & \\
\hline $\begin{array}{l}\text { Wilderness (rustic) campsites with } \\
\text { basics (sharing toilets \& showers) }\end{array}$ & & 0.733 & & & \\
\hline $\begin{array}{l}\text { Campsites must be located close to } \\
\text { wildlife attractions (waterholes). }\end{array}$ & & 0.615 & & & \\
\hline $\begin{array}{l}\text { Shared communal ablution } \\
\text { facilities and wash-up area }\end{array}$ & & & 0.910 & & \\
\hline $\begin{array}{l}\text { Limited number of stands (2-4) } \\
\text { sharing ablution and wash-up areas }\end{array}$ & & & 0.484 & & \\
\hline Campsite must have rooftop tents. & & & & 0.816 & \\
\hline $\begin{array}{l}\text { Fully equipped wilderness trailer } \\
\text { rent from SANParks }\end{array}$ & & & & 0.773 & \\
\hline $\begin{array}{l}\text { Campsite facilities must have a } \\
\text { laundromat. }\end{array}$ & & & & 0.711 & \\
\hline $\begin{array}{l}\text { Campsite ablution facilities must } \\
\text { only have showers. }\end{array}$ & & & & & 0.862 \\
\hline $\begin{array}{l}\text { Campsite ablution facilities must } \\
\text { have a shower and a bath. }\end{array}$ & & & & & -0.685 \\
\hline
\end{tabular}

\section{Ecolodge preferences}

Ecolodge preferences include 30 constructs from which six factors were extracted that refer to all the facilities and services (attributes) at an ecolodge, namely reception, accommodation, restaurant shops and activities, to name but a few. Two factors, namely Factor 3 (remoteness/wilderness) and Factor 6 (reservations), had Cronbach's alpha values that are not statistically acceptable and are therefore excluded from the discussion. Factor 4 (eco/green) was seen as the most important factor with a mean value of 3.13. This factor included constructs for an ecolodge such as eco-labelled products, a recycling plan, a bat hotel for the controlling of mosquitos, and camps that are built with locally made materials. The second most important factor was Factor 2 (facilities) that had a mean value of 3.08 and included constructs such as activities for children, a swimming pool, a laundromat, provision for people with disabilities, a restaurant and a general shop (kiosk). Attributes (Factor 1) was rated as the third most important factor with constructs such as rest camps with field guides, interpretive/educational trails/centres, provision of traditional and local food, a variety of outdoor activities and graded facilities. 
Table 3: Ecolodges

\begin{tabular}{|c|c|c|c|c|c|c|}
\hline Variance explained $56.55 \%$ & $\begin{array}{l}\text { Factor 1: } \\
\text { Attributes }\end{array}$ & $\begin{array}{l}\text { Factor 2: } \\
\text { Facilities }\end{array}$ & $\begin{array}{lr}\text { Factor } & 3: \\
\text { Remoteness/Wilderness }\end{array}$ & $\begin{array}{l}\text { Factor 4: } \\
\text { Eco/Green }\end{array}$ & $\begin{array}{l}\text { Factor 5: } \\
\text { Amenities }\end{array}$ & $\begin{array}{l}\text { Factor 6: } \\
\text { Reserva- } \\
\text { tions }\end{array}$ \\
\hline Cronbach's alpha & 0.849 & 0.739 & 0.377 & 0.801 & 0.651 & 0.342 \\
\hline Mean value & 2.98 & 3.08 & 2.24 & 3.13 & 2.54 & \\
\hline Inter-item correlations & 0.416 & 0.273 & 0.134 & 0.451 & 0.385 & 0.222 \\
\hline $\begin{array}{l}\text { Ecolodges must provide guided field trips or } \\
\text { safaris. }\end{array}$ & 0.773 & & & & & \\
\hline $\begin{array}{l}\text { Ecolodges must provide interpretive and } \\
\text { educational centres. }\end{array}$ & 0.730 & & & & & \\
\hline $\begin{array}{l}\text { Ecolodges must provide qualified field } \\
\text { guides. }\end{array}$ & 0.689 & & & & & \\
\hline $\begin{array}{l}\text { Ecolodges must include wildlife products } \\
\text { (e.g. rugs from animal hides). }\end{array}$ & 0.688 & & & & & \\
\hline $\begin{array}{l}\text { Ecolodges must use locally made décor (e.g. } \\
\text { paintings and chair). }\end{array}$ & 0.597 & & & & & \\
\hline $\begin{array}{l}\text { Ecolodges must provide a variety of outdoor } \\
\text { activities. }\end{array}$ & 0.572 & & & & & \\
\hline $\begin{array}{l}\text { Restaurants must provide traditional food of } \\
\text { the area. }\end{array}$ & 0.484 & & & & & \\
\hline $\begin{array}{l}\text { Ecolodges (camping and accommodation } \\
\text { units) must be themed. }\end{array}$ & 0.469 & & & & & \\
\hline $\begin{array}{lll}\text { Ecolodges } & \text { must be graded by legitimate } \\
\text { grading } & \text { organisations } & \text { (Eco-grading, } \\
\text { TGCSA). } & & \\
\end{array}$ & 0.396 & & & & & \\
\hline $\begin{array}{l}\text { Ecolodges must provide activities for } \\
\text { children (playground). }\end{array}$ & & 0.600 & & & & \\
\hline $\begin{array}{l}\text { Ecolodges must have a swimming } \\
\text { pool/splash pool. }\end{array}$ & & 0.580 & & & & \\
\hline Ecolodges must have a laundromat. & & 0.529 & & & & \\
\hline Caravan- and tentsite areas must be mixed. & & 0.525 & & & & \\
\hline $\begin{array}{l}\text { Allocation of campsite should be on a first- } \\
\text { come, first-served basis. }\end{array}$ & & -0.304 & & & & \\
\hline $\begin{array}{l}\text { Ecolodges need to provide for the needs of } \\
\text { disabled tourists. }\end{array}$ & & 0.357 & & & & \\
\hline Ecolodges must provide a restaurant. & & 0.327 & & & & \\
\hline $\begin{array}{l}\text { Ecolodges must provide a general shop (or } \\
\text { kiosks). }\end{array}$ & & 0.400 & & & & \\
\hline $\begin{array}{l}\text { Ecolodges must be only accessible by } 4 \times 4 \\
\text { vehicles. }\end{array}$ & & & .797 & & & \\
\hline $\begin{array}{l}\text { Ecolodges must be only accessible by high- } \\
\text { clearance vehicles (not necessarily } 4 \times 4 \text { s). }\end{array}$ & & & 0.576 & & & \\
\hline Ecolodges must not be fenced. & & & 0.563 & & & \\
\hline $\begin{array}{l}\text { Ecolodges must use eco-labelled products } \\
\text { (e.g. liquid soap and pesticides). }\end{array}$ & & & & 0.873 & & \\
\hline $\begin{array}{l}\text { Ecolodges must implement a plan to } \\
\text { recycle. }\end{array}$ & & & & 0.855 & & \\
\hline $\begin{array}{l}\text { Ecolodges must have bat hotels to manage } \\
\text { mosquitoes. }\end{array}$ & & & & 0.652 & & \\
\hline $\begin{array}{l}\text { Camps should be built from locally made } \\
\text { materials (wood and bricks). }\end{array}$ & & & & 0.527 & & \\
\hline $\begin{array}{l}\text { Restaurants need to provide halaal and } \\
\text { kosher foods. }\end{array}$ & & & & 0.454 & & \\
\hline Ecolodges must provide DSTV. & & & & & -0.790 & \\
\hline Ecolodges must provide Wi-Fi. & & & & & -0.691 & \\
\hline $\begin{array}{l}\text { Caravan- and tentsite areas must be } \\
\text { separate. }\end{array}$ & & & & & -0.549 & \\
\hline $\begin{array}{l}\text { Ecolodges must provide a client-friendly } \\
\text { booking system. }\end{array}$ & & & & & & 0.671 \\
\hline $\begin{array}{l}\text { There should be strict allocation of available } \\
\text { campsites according to numbers. }\end{array}$ & & & & & & 0.393 \\
\hline
\end{tabular}




\section{Findings and implications}

First, the research found new fixed-roof accommodation preferences as well as confirmed previous ones. The research also confirms the notion by Wight (1997) that ecotourists are looking for a range of accommodation products; the notion is supported by the (1) wilderness accommodation, (2) guesthouse, and (10) chalet factors. It implies that in this case, national parks should offer ecotourists the opportunity to choose between different types of accommodation. This would also offer different income groups or markets the opportunity to visit a national park, since different types of accommodation would generally have different rates. The research further confirms Wight's statement (1997) that the setting is paramount; two factors support this notion, namely setting (Factor 4), which had the second highest mean value, and ambience (Factor 3 ), which had the sixth highest value. It is important to note that the difference between these mean values is small; they are thus equally important. Again, this implies that the location and layout of fixed-roof accommodation must be well researched before development takes place. Accommodation must therefore be located in such a manner that ecotourists are able to experience nature. This research furthermore supports findings by Du Plessis et al. (2013), Tsagarakis et al. (2011) and the report by the International Funding Corporation (IFC, 2002) that highlighted respondents' view that green and environmentally friendly aspects are very important. It also confirms the trend that more and more tourists are becoming environmentally conscious. Ablution facilities (Factor 7) were also found to be important by research that was conducted by Kwan et al. (2010); this implies that accommodation units must have shower or bath options available for ecotourists.

Newly identified aspects that have not been found in the literature before are cooking area (Factor 8) and amenities (Factor 6). Cooking area had the highest mean value and the reason could be that South Africans are traditionally outdoor people and love to prepare food in the outdoors. Self-catering is thus important, especially for tourists travelling to national parks, as most tourists to national parks in South Africa prefer to prepare their own food (Scholtz et al., 2012). In addition, this research also confirms that food is an essential need and has to be catered for in the development of accommodation establishments. Cooking therefore plays an essential role in the total visitor experience in national parks. This also supports Wight's notion (1997) that the experience determines the accommodation type. It implies that the parks authorities should continue to provide cooking facilities (with the necessary kitchen utensils and appliances as required by ecotourists) when they develop such type of accommodation. Outside cooking areas must be built as an extension of the accommodation unit, giving tourists access to the surrounding nature while preparing food. Regarding amenities, it implies that park management must ensure that accommodation units or ecolodges include outside showers and offer accommodation within Big 5 areas where possible. The research also found that accommodation units must represent local culture and tradition in the décor in order to be more authentic.

Second, the research found that campsite preferences differ significantly from fixed-roof accommodation needs and ecolodge preferences; this implies that a different approach or strategy should be followed by parks authorities. It seems that privacy is more important to campers compared to those staying in fixed-roof accommodation. This supports research by Kruger et al. (2012). The lack of research concerning camping needs in nature-based products or national parks makes it difficult to compare all these results. Looking at older campsites in South African National Parks, one finds that allocated camping areas are located directly next to each other, with little chance of being private. The finding has two development implications for national parks: In the first place, it implies that newly planned campsites or campsites that are earmarked for upgrades should accommodate a smaller number of campers (six to eight stands or plots) and each stand or plot should have its own small ablution/kitchen unit where possible. Stands or plots need to be placed in such a manner that there is more privacy and exclusivity for campers. In the second place, it implies that campsites need to be situated close to natural or scenic areas such as waterholes to provide ecotourists with a wilderness experience (see Factors1, 2, 3 and 4).

Third, the research found that new and existing factors were identified and confirmed by this study regarding the needs and preferences for an ecolodge. Existing factors include the application of eco/green principles, which had the highest mean value. This confirms research by Du Plessis (2012), Tsagarakis et al. (2011) and IFC (2002). The finding correlates once again with the results concerning fixed-roof accommodation. It therefore implies that park authorities need to apply green principles when they develop and manage new ecolodges. This principle is important for ecolodges and fixed-roof accommodation. It furthermore implies that ecolodges need to adhere to ecofriendly principles, make use of renewable resources, recycle waste and make use of environmentally friendly products such as biodegradable washing liquids. The same applies to remoteness/wilderness that supports research by Kruger et al. (2012) and Kwan et al. (2015). Attributes (Factor1) also confirms research by Van Loggerenberg (2015), who highlights the importance of interpretation and qualified field guides, as well as research by Engelbrecht (2015) and De Witt et al. (2014), who stress the importance of locally made décor and the offering of a variety of activities. Park authorities, therefore, need to provide or develop these attributes in ecolodges. Ecolodge developments need to fit in with the natural surroundings and building material that is used for the development of accommodation units and other facilities must be locally sourced and made of environmentally friendly products where possible. A new factor that has been identified is facilities (Factor 2). This implies that park management must include facilities for children, a swimming pool, a laundromat and off-road trailers for rent. In many cases, children play an important role in parents' choice of a destination (Van Loggerenberg, 2015). Therefore, it is important to cater for children in national parks. This requires research by park 
authorities in order to ensure that they meet the needs of children in national parks.

\section{Conclusion}

The aim of this exploratory and novel research was to determine tourists' accommodation needs and preferences in the Tsitsikamma National Park, South Africa. Three factor analyses were conducted on aspects regarding fixed-roof accommodation, campsite and ecolodge preferences. Factors that were identified as important when selecting fixed-roof accommodation in national parks are cooking area, setting and ablution. Regarding campsite preferences, respondents identified exclusivity and amenities as the most important factors and for ecolodges, eco/green and facilities were rated as the most important factors. It was difficult to compare these results with previous research, as limited research is available in this regard; the latter was also noted by Kwan et al. (2012).

The research revealed an important finding, namely that fixed-roof accommodation preferences differ significantly from campsite preferences, which implies that accommodation needs and preferences differ from one type of accommodation to the next. This fact was confirmed when ecolodges with fixed roofs and camping were compared.

Several contributions were made by this research: First, it identified ecotourists' preferences for fixed-roof accommodation, ecolodges and camping. Second, to the authors' knowledge, this was the first time that such research regarding accommodation preferences was conducted in South Africa as well as for national parks. Third, the research made a contribution to the current literature regarding ecotourism and ecotourists' accommodation preferences, showing that in developing accommodation in national parks, one also needs to look at other aspects of the tourists' experiences such as the offering of a variety of accommodation, the application of ecofriendly practices, the provision of cooking facilities, interpretation and children activities. Fourth, it contributed in providing guidelines for the development of future accommodation and camping in national parks to suit the preferences of ecotourists. If the research by Wight (1997) is correct in stating that in most cases, ecotourism trends spill over to the larger tourism industry, this research can also influence accommodation preferences in general.

\section{Acknowledgements}

The authors would like to acknowledge the NRF and SANParks for funding, as well as the reviewers for their comments and improving the manuscript. Also the respondents for completing the questionnaires.

\section{References}

Brooker, E. \& Joppe, M. 2013. 'Trends in camping and outdoor hospitality-An international review', Journal of Outdoor Recreation and Tourism, 3: 1-6.
Carruthers, J. 1995. The Kruger National Park: A social and political history. 1st Edition. Scottsville, South Africa: University of Natal Press.

Chan, J.K.L. \& Baum, T. 2007. 'Motivation factors of ecotourists in ecolodge accommodation: the push and pull factors', Asia Pacific Journal of Tourism Research, 12(4): 349-364.

Child D. 2006. The essentials of factor analysis. 3rd Edition. New York: Continuum International Publishing.

Cini, F. \& Saayman, M. 2013. 'Understanding visitor's image of the oldest marine park in Africa', Current Issues in Tourism, 16(7-8): 664-681.

Clark, R.N., Hendee, J.C. \& Campbell, F.L. 2009. 'Values, behavior, and conflict in modern camping culture', Journal of Leisure Research, 41(3): 377-393.

De Witt, L., Van der Merwe, P. \& Saayman, M. 2014. 'Critical ecotourism factors applicable to national parks: A visitor perspective', Tourism Review International, 17(3): 179-194.

Dolnicar, S., Crouch, G.I. \& Long, P. 2008. 'Environment-friendly tourists: What do we really know about them?', Journal of Sustainable Tourism, 16(2): 197-210.

Du Plessis, L., Van der Merwe, P. \& Saayman, M. 2013. 'Tourists' perceptions on whether South African national parks are environmentally friendly', Acta Academica, 45(1): 187-208.

Engelbrecth, W.H. 2015. Developing a competitiveness model for South African National Parks. (Doctoral dissertation, North-West University).

Engelbrecht, W.H., Kruger, M. \& Saayman, M. 2014. 'An analysis of critical success factors in managing the tourist experience at the Kruger National Park', Tourism Review International, 17(4): 237252.

Garst, B.A., Williams, D.R. \& Roggenbuck, J.W. 2009. 'Exploring early twenty-first century developed forest camping experiences and meanings', Leisure Sciences, 32(1): 90-107.

Hermann, U. 2015. A sustainable management strategy for Mapungubwe National Park (Doctoral dissertation, North-West University).

International Finance Corporation (IFC). 2004. Eco lodges: Exploring opportunities for sustainable business. IFC: Washington.

Kruger. M., Viljoen, A. \& Saayman, M. 2013. 'Who pays to view wildflowers?', Journal of Ecotourism, 12(3): 146-164.

Kruger, M., Scholtz, M. \& Saayman, M. 2012. Executive summary of research profiles of selected National Parks in South Africa over 10 years. Potchefstroom, South Africa: Tourism Research in Economic Environs and Society (Research report).

Kwan, P., Eagles, P.F. \& Gebhardt, A. 2010. 'Ecolodge patrons' characteristics and motivations: A study of Belize', Journal of Ecotourism, 9(1): 1-20.

Mehta, H., Baez, A. \& O'Laughlin, P. 2002. Site selection, planning and design. In Mehta, H. (Ed.). International ecolodge guidelines. Burlington: The International Ecotourism Society. 
Morrisonm A.J. 2002. 'Small hospitality businesses: Enduring or endangered', Journal of Hospitality and Tourism Management, 9(1): $1-11$

Pallant, J. 2010. A step by step guide to data analysis using the SPSS program: SPSS survival manual. 3rd Edition. Sydney: Allen \& Unwin.

Pietersen, J. \& Maree, K. 2007. Standardisation of a questionnaire: First steps in research. 1st Edition. Pretoria, South Africa: Van Schaik

Russell, D., Bottril, C. \& Meredith, G. 1995. International ecolodge survey. In Hawkins, D.E., Woods, M.E. \& Bittman, S. (Eds.). The ecolodge sourcebook: for planners and managers. Burlington:mThe International Ecotourism Society.

Saayman, M. 2007. En route with tourism: An introductory text. 1 st Edition. Potchefstroom, South Africa: Platinum Press.

Saayman, M., Rossouw, R. \& Saayman, A. 2012. 'Does conservation make sense to local communities?', Development Southern Africa, 29(4): 588-609.

Saayman, M. \& Scholtz, M. 2012. Visitors' perceptions of the nonconsumptive value of selected species and game-viewing experiences in South African National Parks. Potchefstroom, South Africa: Tourism Research in Economic Environs and Society (Research report).

Saayman, M., Van der Merwe, P. \& Pienaar, J. 2009. 'Expenditure based segmentation of tourists to Kruger National Park', Acta Academica, 41(3): 107-127.

Sanders, E.G. \& Halpenny, E. 2001. The business of ecolodges: A survey of ecolodge economics and finance. Burlington: International Ecotourism Society.

SANParks. 2015. Garden Route (Tsitsikamma, Knysna, Wilderness) National Park. [online] http://www.sanparks.org/parks/ garden_route/about/park_history.php.

Scholtz, M., Kruger, M. \& Saayman, M. 2012. 'The influence of the economic recession on visitors to the Kruger National Park', Journal of Economic and Financial Sciences, 5(1): 241-164.

The International Ecotourism Society see TIES

TIES. 2015. A simple user's guide to certification for sustainable tourism and ecotourism. Washington: Center for Ecotourism and Sustainable Development.

Tsagarakis, K.P., Bounialetou, F., Gillas, K., Profylienou, M., Pollaki, A. \& Zografakis, N. 2011. 'Tourists' attitudes for selecting accommodation with investments in renewable energy and energy saving systems', Renewable and Sustainable Energy Reviews, 15(2): 1335-1342.

Van der Merwe, P. \& Saayman, M. 2008. 'Travel motivations of tourists visiting Kruger National Park’, Koedoe, 50(1): 154-159.

Van Hoven, W. 2005. Ecotourism and game ranching: why it works. Paper presented at Ecotourism South Africa Confex, 9-11 November, Johannesburg, South Africa.
Van Loggerenberg, E. 2015. Development of an interpretation framework for the Kruger National Park (Doctoral dissertation, North-West University).

Weaver, D.B. \& Lawton, L.J. 2002. 'Overnight ecotourist market segmentation in the Gold Coast hinterland of Australia', Journal of Travel Research, 40(3): 270-280.

Wight, P.A. 1997. 'Ecotourism accommodation spectrum: Does supply match the demand?', Tourism Management, 18(4): 209-220.

Wigley, C.J. 2011. 'Cronbach's Alpha versus Components of Variance Approach (COVA): dispelling three myths about alpha and suggesting an alternative reliability statistic for communication trait research', Communication Research Reports, 28(3): 281-286. 